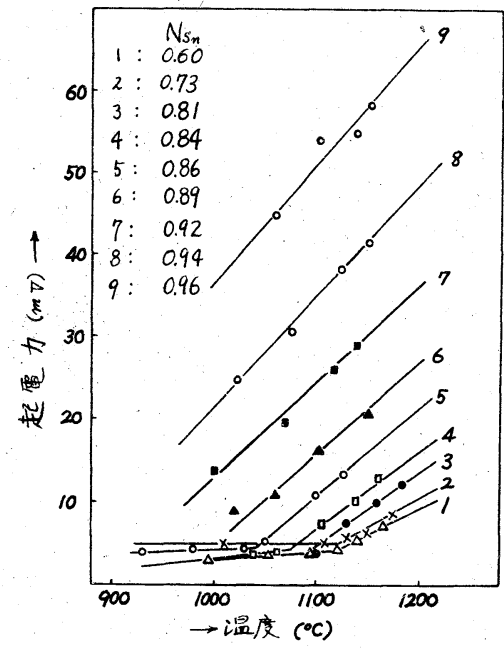

酸塩中の $\mathrm{SnO}$ の活量を增大させることが明らかにされた。 つぎに $\mathrm{Fe}-\mathrm{Sn}$ 系に関する第 3 図のような実験結果に もとづいて $-2 \mathrm{EF}=\mathrm{RT} \ln a_{\mathrm{Fe}}$ なる式に従って $\mathrm{Fe}-$ $\mathrm{Sn}$ 合金中の鉄の活量をまたその $a_{\mathrm{Fe}}$ にもとづいて Gibbs - Duhem の式飞従って錫の活量を決定すること ができる。

第 5 図はこのようにして求めた $1100^{\circ} \mathrm{C} に$ 打ける両成

\section{第4図}

起電力測定値 (Cell II)

$1100^{\circ} \mathrm{C} k$ 打外万 $\mathrm{Fe}-\mathrm{Sn}$ の成分の活量

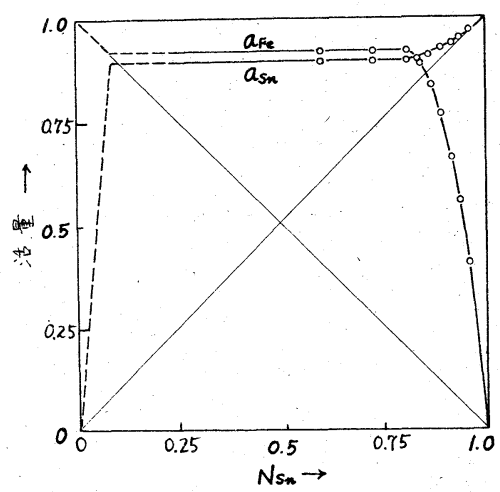

分の活量曲線を示す。この図からともにRaoult の法則 より著しく正の方に偏倚した活量变化を示すことが明ら かにされた。第 4 図に示す Cell II の起電力測定結果に もとづいて混合のための自由エネルギ一変化, 熱量変化, エントロピー変化の partial值を算出した。また試料 番号 No. 1 〜 では起電力ー温度関係図がある温度で勾 配をかえる二つの直線によって表わされているが，これ はその温度以上では均一液相で存在し，その温度以下で は固相が析出することを示すものである。本実験結果か ら推定される液相線は C a m be 11 らの状態図とよく一 致する。

\title{
1406 錫製鍊に関する基礎的研究
}

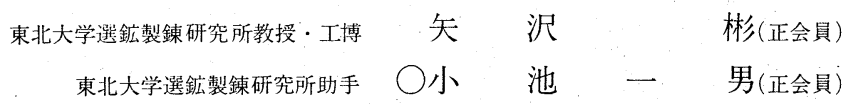

（第1報）錫一鉛, 錫一ビスマスおよび 錫一 タリウム 系溶融合金の活量について

\section{1.緒言}

報告者らは錫製鍊に関する種々の問題飞ついて基礎的 飞解明してゅく予定であるが，本報では溶融錫中の鉛， ビスマス打よびタリウムの挙動を知るために。 $1100^{\circ} \mathrm{C}$ を中心にして流動法に上り蒸気圧を測定し, 活量を求め ていくつかの熱力学的な考察を試みた。

これらの系の活量がわかると, 錫溶鍊に打ける不純物 の除去飞関する知識が得られる住か，錫彆鍊でとくに問 題の多い錫一鉄合金の活量を分配平衡に上り求めるため の基礎資料になる。これらの系江関する活量測定はいく つかあるが、ほとんどが低温で行なわれでり，また実 験結果は必ずしも一致していない。

\section{2. 実験方法}

実験は流動法による蒸気圧測定により行なったが、こ れについては先に矢沢らが他の系について報告してい るのでこっでは省略する。

\section{3. 実験結果および熱力学的考察}

\section{$3 \cdot 1$ 錫一鉛采}

$1000^{\circ} \sim 1200^{\circ} \mathrm{C}$ に招ける純鉛の蒸気圧を測定したと ころ，従来の值と良く一致していて，本報の実験装置， 方法などの妥当性を示している。 $1000^{\circ} \sim 1200^{\circ} \mathrm{C}$ 飞招
いて,まず鉛の活量を定めたが， $1100^{\circ} \mathrm{C}$ 飞打りる錫一 鉛系の活量曲線を第 1 図に示した。 $\alpha_{\mathrm{pb}}=\ln \gamma_{\mathrm{pb}} /(1-$ $\left.N_{\mathrm{Pb}}\right)^{2}$ で定義される $\alpha$ 関数壳計算したところ, 大体一定 值を示したので, 錫の活量係数は $\ln \gamma_{\mathrm{Sn}}=\alpha_{\mathrm{pb}_{\mathrm{b}}} N_{\mathrm{p}_{\mathrm{b}}}^{2}$ なる 関係を利用して求めることができる。四からわかるよ5

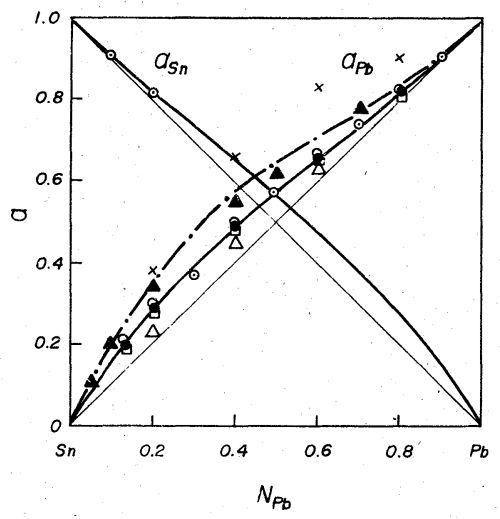

- 本実験 $\left(1100^{\circ} \mathrm{C}\right), \quad \circ\left(1000^{\circ} \mathrm{C}\right), \quad \square\left(1200^{\circ} \mathrm{C}\right)$, - Elliott, Chipman $\left(500^{\circ} \mathrm{C}, \mathrm{Sn}-\mathrm{pb}^{\prime}-\mathrm{Cd}\right.$ 系 emf ), Atarashiya, etal $\left(800^{\circ} \mathrm{C}\right.$ 還元平衡) $\triangle$ 後藤, セントビエール $\left(800{ }^{\circ} \mathrm{C}\right.$, 固体電解質に上る e mf $)$

$\times$ Hawk ins, Hul tgren $\left(1050^{\circ} \mathrm{K}\right.$, 回転流出法)

$\odot$ 状態図より計算 $\left(1100^{\circ} \mathrm{C}, \mathrm{H}\right.$ ansen $の$ 状態図ょり)

第工図錫一鉛系の活量 


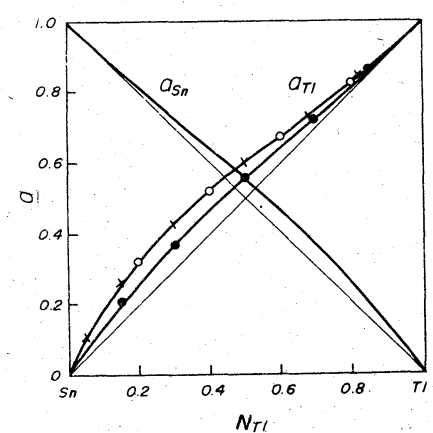

- 本実験 $\left(1050^{\circ} \mathrm{C}\right.$, 流動法) - Hildebrand $\left(478^{\circ} \mathrm{C}\right.$ emf $)$ $\times \mathrm{V}$ ierk $\left(462^{\circ} \mathrm{C}\right.$, emf $)$

第2図錫一タリウム系の活量

に, 理想状態よりや〉正に偏倚している。他の研究者ら の結果も同時に図示したが, E11 i ot t らの結果飞つい ては温度差を考虑すると報告者らの結果と大体合致して いる。

$1000^{\circ} \mathrm{C}, 1200^{\circ} \mathrm{C}$ 亿つての測定結果は $1100^{\circ} \mathrm{C} の$ 值に近接しており，温度勾配から混合熱を計算すると多 少の誤差を生ずると思われるので, 混合のェネルギー を計算して， $\Delta H=\omega N_{\mathrm{pb}} N_{\mathrm{sn}}$ 亿よって求めた。

$\alpha$ 関数が全組成にわたってほが一定值を示したことか ら推察して, この系の棈成原子の分布は全領域にわたっ て無秩序な正規溶液に近いと思われる。な扣錫一鉛系の 平衡状態図よりそれぞれの活量を計算して第 1 図に示し たが，正規溶液を仮定したこの計算值は測定值と良く一 致している。しかしながら他の研究者らの一部は, この 亲は正規溶液ではないという結果を報告している。

次に溶融錫中の鉛を除去する際に重要な無限希薄溶液 に打ける鉛の活量係数 $\gamma_{\mathrm{pb}}^{\circ}$ を計算したところ 1.7 となっ たが，両金属の蒸父任の差や酸素との親和力などを考光 合わせると, 錫中の鉛は乾式精製では比較的除去しにく いと思わ机る。

3・2 錫一タリウム系

第 2 図に $1050^{\circ} \mathrm{C}$ に扣ける活量曲線を示している。 $\alpha$ 関数は一定值を得て, この系も大体正規溶液とみなして 上い:

3・3錫一ビスマス系

ビスマスは蒸気相に扣いて $\mathrm{Bi}, \mathrm{Bi}_{2}$ 亿解離することが 知られているので, 蒸気压执よび活量の算出は今までの 計算とは異なりかなり複雑になる。実験結果ならびに計 算值を第 1 表に示し, 活量曲線を第 3 図に示したが, こ の系は理想溶液に近いことを示している。 $0.5 \mathrm{~N}$ 亿拈け る混合熱をやはり りまた $\gamma_{\mathrm{Bi}}^{\circ}$ は 1.1 となった。

第1表 錫一ビスマス合金采の 1100 C レ打ける測定結果

\begin{tabular}{|c|c|c|c|c|c|}
\hline 組 成 & $P_{m}$ & $P_{\mathrm{Bi}}$ & $P_{\mathrm{Bi}_{2}}$ & $P_{\mathrm{Bi} T}$ & $a_{\mathrm{Bi}}$ \\
\hline 純ビスマス & $2.41 \times 10^{-2}$ & $8.74 \times 10^{-3}$ & $7.72 \times 10^{-3}$ & $1.65 \times 10^{-2}$ & \\
\hline $\begin{array}{l}26 \text { at } \% \\
\text { ピスマス }\end{array}$ & $3.45 \times 10^{-3}$ & $2.34 \times 10^{-3}$ & $5.53 \times 10^{-4}$ & $2.89 \times 10^{-3}$ & 0.268 \\
\hline 50 & $8.33 \times 10^{-3}$ & $4.41 \times 10^{-3}$ & $1.96 \times 10^{-3}$ & $6.37 \times 10^{-3}$ & 0.504 \\
\hline 75 & $1.51 \times 10^{-2}$ & $6.54 \times 10^{-3}$ & $4.32 \times 10^{-3}$ & $1.09 \times 10^{-2}$ & 0.750 \\
\hline
\end{tabular}

たら゙し $P_{m}$ は見掛けの蒸気压ですべて単原子ガスとした場合の值。

3.4 錫一鉛一ビスマス系

Vol.84 No.959('68-3)

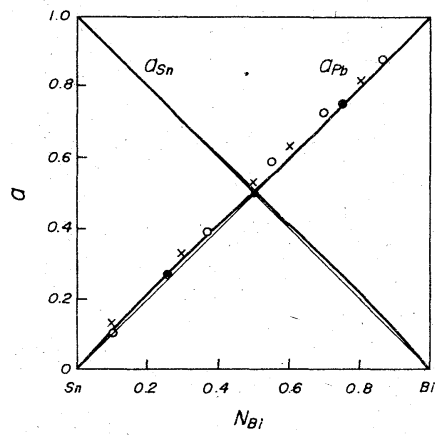

- 本実験 $\left(1100^{\circ} \mathrm{C}\right.$, 流動法)

。千葉・松島 $\cdot$ 小野 $(900 \mathrm{~K}$, emf $)$

$\times$ Selt $z$, Dunkerley $\left(608.1^{\circ} \mathrm{K}\right.$, emf )

第3図錫一ビスマス系の活量

Toop 3 は 2 元系のデータを用いて, 3 元系の活量を求 める計算について報告しているが, 報告者らの実験值と 鉛一ビスマス系に関するHultgren $5^{4)}$ のまとめた数值 を利用して，錫一鉛一ビスマス 3 元系の $1100^{\circ} \mathrm{C} に$ 打け る活量を計算した。

\section{4. 結言}

流動法によって高温における錫一鉛, 錫一タリウム, 錫一ビスマス系の活量を求めたところ, 前二者はほら゙正 規溶液, 後者は理想溶液に近いことがわかった。むた, To op の方法を利用して錫一鉛一ビスマス 3 元系の $1100^{\circ} \mathrm{C}$ に扣ける等活量線を求めた。

\section{文献}

1) 矢沢彬・阿座上竹四・川島崇司：日本鉣業会誌，82巻 938 号， (1966) D. 519.

2 ) Darken, Gurry: Physical chemistry of Metals, MCGRAW - HILL Book Co, (1953) p. 264.

3) G.W. Toop: Trans. A IME. Vol.233, (1965) p.850.

4) R.Hultgren etal : Selected Values of Ther modynami c Properties of Metals and Alloys, John Wiley (1963) p.540

\section{（第2 報）分配平衡法による溶融錫一鉄合金 の活量測定}

$$
\text { 1. 緒言 }
$$

錫の乾式製鍊では溶融錫中の各種不純物の熱力学的な 挙動や，鉱石，中間産物拈よびスラグなどの物理化学的 性質を知ることが重要であるが，いまだにそれらの詳し い報告は少ない。とくに鉄は錫製錬に多量に伴なうもの であり，しか子酸素に対する親和力が鉄と錫は比較的近 いので, その挙動は極めて重要である。前報では鉄と完 全 2 液分離をなす鉛, ビスマス、タリウムをとりあげ, それらの錫との溶融合金の活量を求めたが，本報ではそ の結果を利用して, 溶融錫一鉄合金の活量を分配平衡法 で測定した。この系の活量については, 平衡状態脑から 計算したものはあるが，実験測定の報告は見当らない。

\section{2. 実 験 方 法}

鉄と鉛を溶かすと，相互溶解がなく2液相を作る。そ れである組成の鉄, 鉛, 錫を一緒飞溶解すると, 錫は雨 相に分配されて平衡に到達して, その時の活量の関係は 


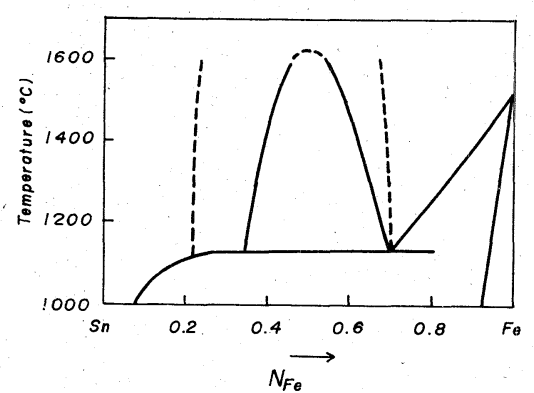

$\leftarrow$

破線はHansen

よる液相範囲

第1図

錫一鉄系の状態図 (高温部)

Davey とよる補正

第 2 図

錫一鉛相 (白丸) と

錫一鉄相 (黑丸) と の共役線 $\left(1350{ }^{\circ} \mathrm{C}\right)$

次のようになる。

$a_{\mathrm{Sn}}($ in $\mathrm{Fe})=a_{S \mathrm{Sn}}($ in $\mathrm{Pb})$

$r_{\text {Sn }}($ i n $\mathrm{Fe})=a_{\text {Sn }}($ in $\mathrm{Pb}) / N_{\text {Sn }}($ i n Fe $) \cdots(2)$

錫一鉛系については前報で報告した通りほぶ正規溶液 で, その活量はわかっているので, 錫一鉄系中の錫の活 量を知ることができる。

種々の組成に調合された試料 $40 \mathrm{~g}$ を高アルミナ質夕 ンマン管に入れ，十分洗浄したアルゴンガス雾囲気中の 不透明石英管飞装入する。反応管は固定されていて、炉 は上下可動式の複ら管シリコニット炉を使用した。実験 は $1350^{\circ} \mathrm{C}$ を心にして行ない, 溶解時間は 3 時間とし 実験終了後は炬を下げて急冷し，2首にわかれた試料に ついて，両層を切断してそれぞれの各成分を分析して活 量を決定した。

な扣，この分配平衡実験では，錫一鉄 2 元融体と，錫

一鉛 2 元融体に分離すれば理想的であるが, 実際問題と

してはとくに錫の多い場合に、錫一鉛系融体相に鉄も入 り込んでくる。したがって活量を正確に推定するために 錫に富んだ錫一鉛一鉄 3 元融体について, 流動法によっ て鉛の烝気圧を測定し、これから必要な活量を算出した。

\section{3. 実 験 結 果}

本報告での実験対象である錫一鉄系について，まず第 1 図に状態図を示した。H a n senのまとめた状態図と D a ve ${ }^{1)}$ の補正したものとは, 2 液相範囲にかなりの違. いがあるが，報告者らはこの 2 液相範囲について 2,3 の溶解実験を行なったところ, Turkdogan らの実験值 を採用しているDavey の補正曲線がより信頼できそう に思われたので, 本報告ではその結果を採用することに した。

第 2 図は錫一鉄一鉛 3 元混合物を溶解して分配実験を 行なった結果を示するので, 白丸と黒丸で結ばれる線は
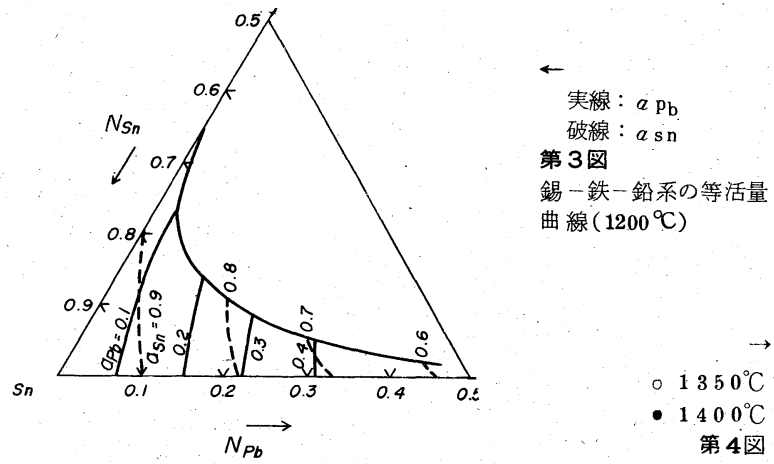

錫一鉛相と錫一鉄相を結ぶ共役線である。図にみられる ように, 錫の多い錫一鉛相にはかなりの鉄が溶解して 3 元系の 2 液相分離線として示されており，したがって前 報で求めた 2 元錫一鉛系の錫の活量をそのま〉利用する ことができない。

そこで流動法によって, 錫一鉄一鉛 3 元系の液体範囲 内で, $1200^{\circ} \mathrm{C}$ に打ける活の活量を測定して鉛の等活量 線を画き，さらにS chuhmannの方法によって錫の活 量を求め, それぞれの等活量線を求めたところ第 3 図の ような傾向を得た。この等活量線を利用して, 錫一鉛側 融体相の錫の活量を定め, 錫一鉄系の錫の活量を算出し た。その結果は第 4 図中の丸印で示す。実験結果にもと ついて得た錫の活量曲線加, Gibbs-Duhem 式飞よっ て鉄の活量を求め, 第 4 図に同時に示した。2 液分離系 の一般的性質の通り，かなり大きく正偏倚している。 この結果は $1350^{\circ} \mathrm{C}$ の実験を主体として求められている が, 温度を変えて測定してもその差は比較的小さなもの であった。

このように錫一鉄系の活量がわかると，錫の乾式製錬 について種々の考察をすることが可能になる。錫の乾式 溶錬は通常 2 段飞わかれ，第 1 段の鉱石吹では鉄の比較 的少ない粗錫を得るが，多量の錫がスラグに損失する。 第 2 段のカラミ吹ではこのスラグをさらに還元するが， この際得られる金属は錫一鉄合金のハードへッドとなる。 これらの工程について熱力学的な考察を行なった。

\section{4. 結}

言

溶融錫一鉄系の活量を分配平衡法で測定し，さらに錫 一鉄一鉛系の均一融体範囲の等活量線を求めて実験值の

- $1350^{\circ} \mathrm{C}$

- $1400^{\circ} \mathrm{C}$

第 4 図

錫一鉄系の活量

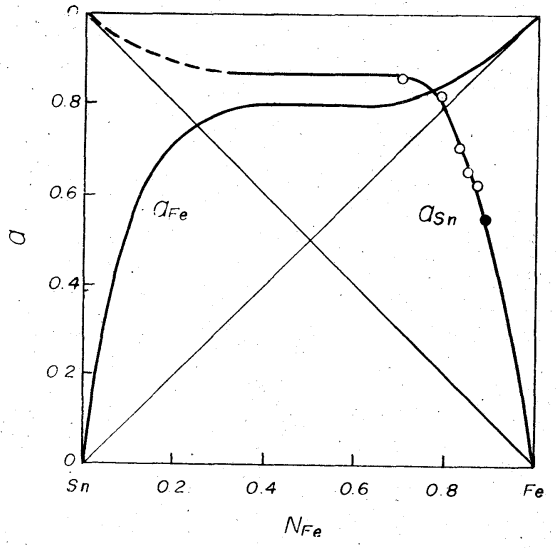


正確さを期した。錫一鉄系の活量はかなり正て偏倚して おり，この性啠は実際製鍊工程に対しても重要な関連を もっている。
文

1) T.R.A. Davey : Trans. I.M.M. 76(1967) C 66.

2) R. Schummann, JR : Acta Met. vol 3, (1955) p 219.

\section{$1407 \mathrm{Cu}-\mathrm{Ag}-\mathrm{Se}$ 系に関する研究（第1 報） 金属相とセレナイド相との間の A g の分配と金属銅相の組織とについて}

$\begin{array}{rrrl}\text { 愛媛大学工学部教授・工博 浅 野 梄 - } & \text { 郎(正会員) } \\ \text { 愛媛大学工学部助手 } \bigcirc \text { 和 瀬 国 } & \text { 臣(准会貝) } \\ \text { 三谷伸銅株式会社 野 村 達 雄 }\end{array}$

\section{1. 緒 富}

一般に銅電解アノードスライム中の $\mathrm{Se}$ は主として $\mathrm{Ag}_{2} \mathrm{Se}$ として存在し，それより飠過剩の $\mathrm{Se}$ が含有され ている場合には $\mathrm{CuAgSe}$ 存在するといわれている。 2) これらは電解によって変化を受けないで，そのままスラ イムとなったものであると考えられているために，粗銅

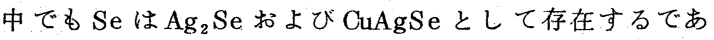
ろ と漠然と仮定されている。

われわれは溶融金属銅相と硫化銅相之の間の諸元素の 分配について測定した結果 ${ }^{33}$ から, $\mathrm{Ag}$ は金属相に, $\mathrm{Se}$ は硫化銅相にそれぞれ濃縮するために転炉吹き製銅期の 大部分の間, 両元素はほぼ分離していると考えられるの で, 粗銅中の Se が Ag と結合しているという考方方に 疑問を抱くようになった。それゆえSが無視できるよう な製銅期の末期または精製炉内に打けるこれら元素の挙 動を理解するために， $\mathrm{Cu}-\mathrm{Ag}-\mathrm{Se}$ 系に打ける金属相と セレナイド相との間の $\mathrm{Ag}$ の分配比を求めるとともに, 溶体が金属銅の単二相となる組成範囲内の少量の $\mathrm{Ag}$ と $\mathrm{Se}$ とを含有する固相の組織を検討することにした。

\section{2. 実 験 方 法}

金属相とセレナイド相との間の $\mathrm{Ag}$ の分配比の測定に は電気銅, 電気銀打よび高純度セレンを適当に配合して 合計約 $7 \mathrm{~g}$, 配合試料中の Seを $15 \%$ とし透明石英管に 真空封入し, $1200 \pm 5^{\circ} \mathrm{C}$ 亿 0.5 時間溶融後炉内で試料 を䚌拌し，引続さ 2.5 時間保持して 2 相に分離した後空 冷し各相の組成を化学分析により決定した。

次にこの結果と $\mathrm{Cu}-\mathrm{Cu}_{2} \mathrm{Se}$ 系 ${ }^{4)}$ 状態図とを参考とし， 溶体が少量の $\mathrm{Ag}$ 打よび $\mathrm{Se}$ を含む単一金属相になる試料 の組成は, $\mathrm{Ag}_{2} \mathrm{Se}$ 亿相当する量比である $\mathrm{Ag} 5.00 \%$ ， Se $1.83 \%$ ，また Ag $8.00 \%$, Se $2.93 \%$ になるよ 飞 $\mathrm{Ag}_{2} \mathrm{Se}$, または $\mathrm{Ag}$ と $\mathrm{Se}$, または $\mathrm{Ag}$ と $\mathrm{Cu}_{2} \mathrm{Se}$ と $\mathrm{Cu}$ 飞添加し前述と同様に溶融後，空冷または炉冷した。冷 却後試料を中央部より切断し顕微鏡試験, 微小硬度計扣

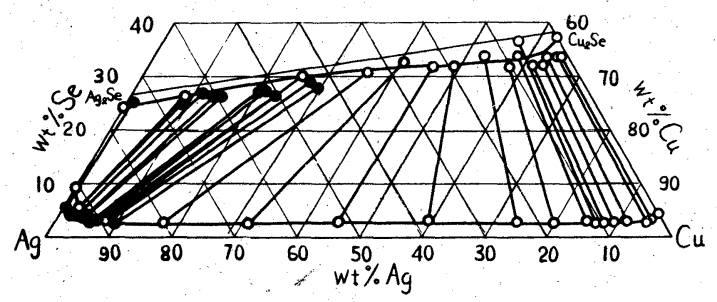

○本研究 $\left(1200^{\circ} \mathrm{C}\right) \cdot \operatorname{Emi}$ cke $\left(950^{\circ} \mathrm{C}\right)$

第1図 $\mathrm{Cu}-\mathrm{Ag}-\mathrm{S}$ e 系に打ける 2 液相分離範丮と対応線
よびX線マイクロアナライザースよりそれらの組織を検 討した。

\section{3. 実験結果亡考察}

3・1 Cu-Ag-Se系における金属相とセレナイド相 との間のAgの分配

$1200^{\circ} \mathrm{C}$ 飞扣ける本系の 2 液相分離範囲および対応す る両相の組成は第 1 図に示すようであって，2 液相分離 範囲は広大であり，その全区域にわたって Ag 亿富む金 属相と $\mathrm{Cu}_{2} \mathrm{Se}$ 亿富むセレナイド相とが対応する。Emicke による $950^{\circ} \mathrm{C}$ の実験結果は併示したよ 5 $\mathrm{Ag}-\mathrm{Ag}_{2} \mathrm{Se}$ 系に近い部分を除いては本研究結果とよく一致していて 温度依存性は少ない。 $\mathrm{Ag}-\mathrm{Ag}_{2} \mathrm{Se}$ 系の 2 液相分離範囲 は第 2 図に示すようであり, 文献の状態図 ${ }^{6)}$ とほら゙一致 しているので, 3 元系の $\mathrm{Ag}-\mathrm{Ag}_{2} \mathrm{Se}$ 系に近い部分は本 研究結果の方が妥当であると考えられる。

両相中の $\mathrm{Ag}$ 含有量の関係は第 3 図, $\mathrm{Ag}$ の分配 比=

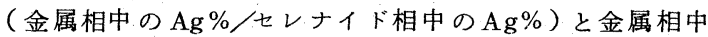
の $\mathrm{Ag} \%$ との関係は第 4 図に示すようになる。 $\mathrm{Ag}$ の分配 比は $\mathrm{Ag}$ の含有量が微量の場合 1.6 であるが, $\mathrm{Ag}$ の含有 量が增加するに彷って次第に大きくなり，金属相中の $\mathrm{Ag}$ が $70 \%$ 近くで 2.5 の最大值に達し, それ以上の $\mathrm{Ag}$ $\%$ では $\mathrm{Ag}-\mathrm{Ag}_{2} \mathrm{Se}$ 系に近づくために減少し, $\mathrm{Ag}-\mathrm{Ag}_{2} \mathrm{Se}$ 系で 1.2 となる。

上述のように $\mathrm{Ag}$ に富む金属相と $\mathrm{Cu}_{2} \mathrm{Se}$ e 富むせレナ イド相とが対応するので, $\mathrm{Cu}$ と $\mathrm{Ag}_{2} \mathrm{Se}$ とは準 2 元系を 構成したり，または $\mathrm{Cu}$ 相と $\mathrm{Ag}_{2} \mathrm{Se}$ 相とが対応すること はなく, $\mathrm{Cu}$ 隅付近飞 $\mathrm{Ag}_{2} \mathrm{Se}$ の初晶面は存在しないもの と考えられる。

少量の $\mathrm{Ag}$ 扣よび $\mathrm{Se}$ を含む $\mathrm{Cu}$ を凝固した試料の显微 鏡試験によると, 空冷の場合は炉冷の場合に比して粒子 が微細であるが，Ag扰よびSeの含有量と冷却方法とが 同一の場合にはAg 执よびSe の添加方法に無関係に同一 組織であって地金の $\mathrm{Cu}$ 中に灰色のセレナイド相と白色

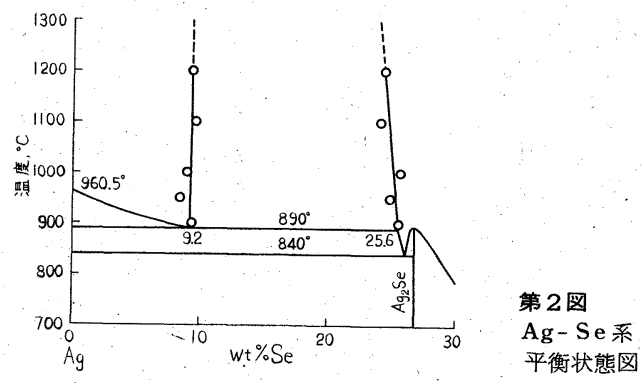

\section{$3 \cdot 2$ 少量の $\mathrm{Ag}$ と $\mathrm{Se}$ とを含有する $\mathrm{Cu}$ の組織}

